Crop Breeding and Applied Biotechnology 5:10-21, 2005

Brazilian Society of Plant Breeding. Printed in Brazil

\title{
Development of rice lines with gene introgression from the wild Oryza gl umaepatula by the AB-QTL methodology
}

Paulo Hideo Nakano Rangel ${ }^{1 *}$, Claudio Brondani ${ }^{1}$, Priscila Nascimento Rangel ${ }^{1}$, Rosana Pereira Vianello Brondani ${ }^{1}$, and Francisco José P. Zimmermann ${ }^{1}$

Received 2 December 2004

Accepted 8 March 2005

\begin{abstract}
Wild rice of the species Oryza glumaepatula is found Brazil and has been used to broaden the genetic basis of irrigated rice populations in Embrapa breeding programs. Objective of this study was to demonstrate and discuss approaches used in the development of Oryza sativa lines containing genes transferred from Oryza glumaepatula, resulting in introgression lines with a broader genetic basis and high yield. First of all, genes were transferred from the wild species to cultivated rice by the AB-QTL methodology. Eighteen families were selected using QTL analysis and agronomical performance data. After the heterosis test the families CNAi 9020 and CNAi 9024 were selected and submitted to microsatellite marker-assisted selection. Thirty-five lines were then selected with high plant vigor, high tiller and panicle number per plant, high grain yield of the main crop, and a strong regrowth capacity which makes the use of ratoons a feasible alternative.
\end{abstract}

Key words: irrigated rice, microsatellite markers, lines, grain yield.

\section{INTRODUCTION}

The yield levels of irrigated rice in Brazil have been in stagnation since the end of the 80 s when the process of substitution of traditional cultivars by modern varieties of short growth type had reached its peak (Castro et al. 1999). One of the main reasons cited for this situation is the narrow genetic base of the planted cultivars, as a result of the intense improvement of modern varieties which reduced the gene pool. According to Rangel et al. (1996), only ten ancestors account for $68 \%$ of the gene pool of the Brazilian varieties of irrigated rice. Considering the most planted cultivars in the main irrigated rice-producing states, the same authors stated that the seven most frequent ancestors in the pedigrees are responsible for $70 \%$ of the genes. Similar results were obtained by Breseghello et al. (1999). This high genetic uniformity may trigger serious consequences for the Brazilian rice production.

A limited genetic variability in the populations in selection affects the gain. Diverse studies have reported genetic gains for grain yield smaller than $1 \%$ in the

${ }^{1}$ Embrapa Arroz e Feijão, C. P. 179, 75.375-000 Santo Antônio de Goiás, GO, Brasil. *E-mail: phrangel@cnpaf.embrapa.br 
improvement programs of irrigated rice conducted in Brazil (Soares et al. 1994, Breseghello et al. 1999, Santos et al. 1999, Rangel et al. 2000).

Wild rice species have been used in genetic improvement programs for broader genetic population bases as much as for the transference of specific traits to cultivated varieties. The use of this germplasm is often hampered since crossings with cultivated rice produce hybrids with various levels of sterility. Besides, the progenies present a series of undesirable traits. One of the alternatives of exploring this variability in genetic improvement programs with a comprehensive mission and working with a series of priorities is the adoption of the pre-breeding phase, which means nothing else than the development of populations or lines through crossings and backcrossings of the exotic germplasm with improved lines. The objective is to transfer useful genes to a genetic environment where they can be used more easily by breeders. This whole process becomes more effective when it is monitored by molecular markers and genetic maps, with the main advantages of creating a larger quantity of data and monitoring the traits that are being transferred.

Of the wild rice species that occur in Brazil, Oryza glumaepatula, which is autogamous, diploid and has a similar genome AA to that of the cultivated species Oryza sativa, is the most auspicious for the use in genetic improvement (Buso et al. 1998, 2001). Objectives of this study are to show and discuss the procedures adopted in the development of Oryza sativa lines with gene introgression from the wild species Oryza glumaepatula and their use in the yield increase and broadening of the genetic base of irrigated rice populations.

\section{MATERIAL AND METHODS}

\section{Gene transference from $O$. glumaepatula to $O$. sativa}

Figure 1 shows the scheme used to obtain the lines of rice with genomic fragments of $O$. glumaepatula. Genes were first transferred from the wild to a cultivated species by Brondani et al. $(2001,2002)$ using the AB-QTL (Advanced Backcross Quantitative Trait Loci Analysis) strategy developed by Tanksley and Nelson (1996). The authors realized the transference in the following steps: a) In 1996, a plant of $O$. glumaepatula accession RS-16 from a wild population of the Amazon region (Buso et al. 1998) was crossed with an elite $O$. sativa line, BG 90-2; b) Establishment of four hybrid $\mathrm{F}_{1}$ plants, confirmed by RAPD (Random Amplified Polymorphic DNA) and SSR (Simple
Sequence Repeat) markers (Cavalheiro et al. 1996), which were backcrossed with BG 90-2 in 1997; c) In 1998, a total of $256 \mathrm{RC}_{1} \mathrm{~F}_{1}$ plants with favorable phenotypic traits were backcrossed again with BG 90-2 leading to generation $\mathrm{RC}_{2} \mathrm{~F}_{1}$, which was selfed to produce $\mathrm{RC}_{2} \mathrm{~F}_{2}$ seeds. Ninetythree $\mathrm{RC}_{1} \mathrm{~F}_{1}$ families were selected for the construction of the genetic map based on the PCR reaction using 162 molecular markers (155 SSR and seven STS - sequencetagged-site markers) (Brondani et al. 2001); d) in the crop year 1999/00, $96 \mathrm{RC}_{2} \mathrm{~F}_{2}$ families, the two genitors (BG 90-2 and RS-16) and the commercial cultivar BR-IRGA 409 (control) were evaluated in the field in an experimental design of randomized complete blocks with three replications. The experiment was conducted on the experimental fields Fazenda Palmital (Goianira, state of Goiás, site 1) and Formoso do Araguaia (Formoso do Araguaia, state of Tocantins, site 2), of Embrapa Arroz e Feijão, using seedling transplanting. The plots consisted of three $3.0 \mathrm{~m}$ long rows with 20 plants each. BG 90-2 was planted along the border rows and the $\mathrm{RC}_{2} \mathrm{~F}_{2}$ families in one central row of each plot where data were collected for eleven agronomical traits. The QTL analyses were carried out using phenotypic data and information from the genetic map (Brondani et al. 2002).

\section{Heterosis tests}

Eighteen $\mathrm{RC}_{2} \mathrm{~F}_{2}$ families were selected based on the genetic map, the QTL analyses and on the phenotypic data, bulk harvested $\left(\mathrm{RC}_{2} \mathrm{~F}_{3}\right)$ and advanced to $\mathrm{RC}_{2} \mathrm{~F}_{4}$ in the winter season (May through October 2000) in the state of Tocantins. The $18 \mathrm{RC}_{2} \mathrm{~F}_{4}$ families plus the controls BG 90-2 and BRS Formoso were evaluated in trials in the crop year 2000/01 in the states Goiás, Roraima and Tocantins to verify whether the increase in the number of panicles and yield were caused by heterosis or by favorable alleles of $O$. glumaepatula. An experimental design of randomized complete blocks with four replications was used; every plot consisted of four $5.0 \mathrm{~m}$ long furrows. Seedling transplanting was used in the trials of Goiás and Tocantins and in Roraima the seeds were planted directly into the dry soil.

The mean data of number of panicles and grain yield in $\mathrm{kg} \mathrm{ha}^{-1}$ per site and in the mean of the three sites were analyzed statistically and the means compared by the test of Scott and Knott (1974) at 5\% probability.

\section{Molecular microsatellite-marker-assisted selection (SSR) in two $\mathrm{RC}_{2} \mathrm{~F}_{6}$ families}

Based on the heterosis tests, two highly productive families (CNAi 9920 and CNAi 9924) were selected for their large number of panicles and because various segments 


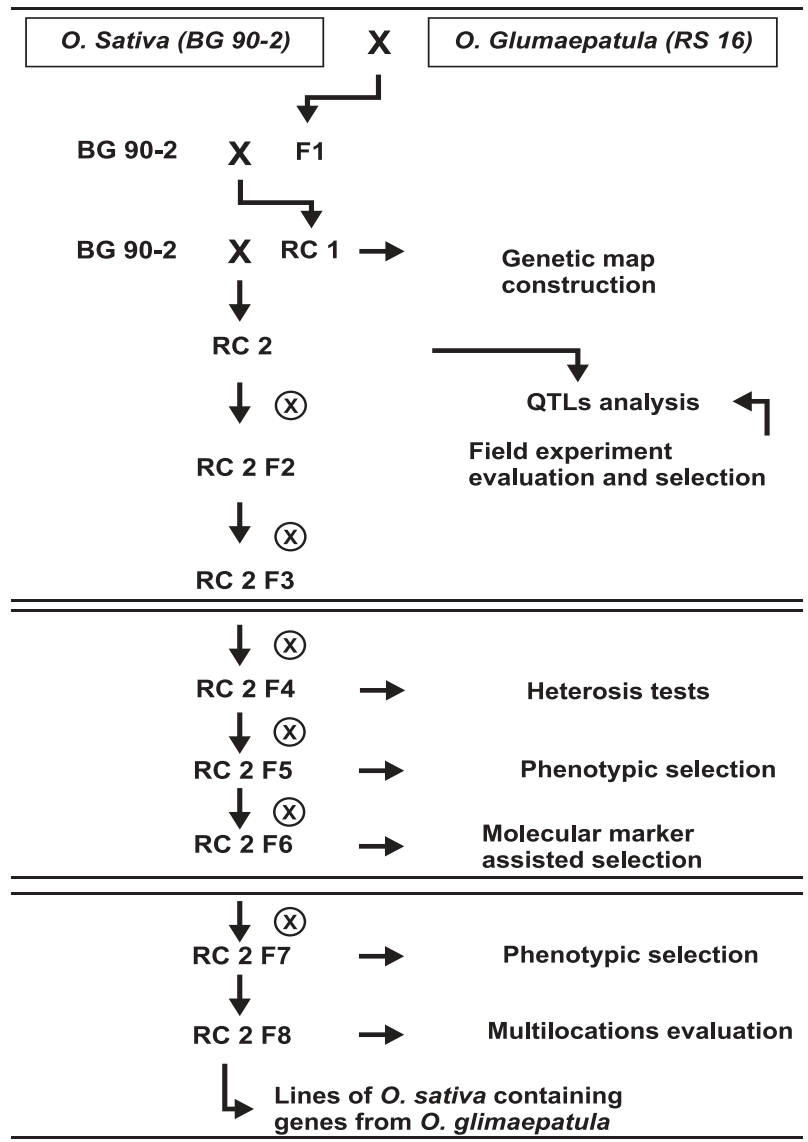

Figure 1. Scheme used in the development of lines of $O$. sativa with gene introgression from the wild species $O$. glumaepatula

in their genotypic constitution contained introgressions of $O$. glumaepatula at estimated percentages of $13 \%$ and $8 \%$, respectively. These families were subjected to markerassisted selection with SSRs.

Two thousand plants of each one of these two families in the $\mathrm{RC}_{2} \mathrm{~F}_{5}$ generation were planted in the field. In the CNAi 9920 and CNAi 9924 families 104 and 168 plants were selected, respectively, considering the number of tillers and panicles and the plant growth type. Ten seeds of each plant in the $\mathrm{RC}_{2} \mathrm{~F}_{6}$ generation were placed in a germinator for 7 to 14 days on germitest paper at $30^{\circ} \mathrm{C}$. The DNA of the germinated seeds was extracted as described by Brondani et al. (1998). Amplification reactions were realized and the amplified loci visualized by electrophoresis in $5 \%$ agarose gel stained with ethidium bromide or in $4 \%$ acrylamide gel dyed with silver nitrate. To reduce the percentage of the $O$. glumaepatula genome introgressed in the lines CNAi 9920 and CNAi 9924 and to increase the phenotypic value for the traits of interest, SSR markers were selected identified by the QTL analysis realized by Brondani et al. (2002): OG60, OG99, RM1, RM2, RM4b, RM10, RM11, RM44, RM163, RM223, RM261, OS22 (Table 2).

The remaining $\mathrm{RC}_{2} \mathrm{~F}_{6}$ seeds of the plants selected by molecular markers in the families CNAi 9920 and CNAi 9924 were taken to the field of the experimental station of Formoso do Araguaia, Tocantins, in June, for another evaluation and phenotypic selection. The seeds were sown into a seedbed and the seedlings taken to the field after 30 days where they were planted in plots of eight furrows of $5.0 \mathrm{~m}$ of length in a spacing of $0.30 \mathrm{~m}$ between furrows and $0.10 \mathrm{~m}$ between plants.

\section{Phenotypic evaluation of 35 lines of Oryza sativa with gene introgression from the wild species Oryza glumaepatula}

Thirty-five families, of which eight were transgressive for grain yield and 27 obtained by molecular markerassisted selection, together with three controls (BG 90-2, Metica 1 and CNA 8502) were evaluated in the experimental design of random blocks with three replications. Every plot was formed by four $5.0 \mathrm{~m}$ long furrows spaced $0.30 \mathrm{~m}$ and the useful plot area consisted of two central $4.0 \mathrm{~m}$ long rows. The sowing density was 100 seeds a meter and the seeds were planted directly into the dry soil. The trial was conducted in Goiás, Tocantins and in Roraima.

The following data were collected in the main crop: mean flowering $(\mathrm{Fl})$, plant height $(\mathrm{Ht})$, lodging $(\mathrm{Lg})$, number of tillers (Ti) and panicles (Pan) per $\mathrm{m}^{2}$ and grain yield (Yld) in $\mathrm{kg} \mathrm{ha}^{-1}$. In the trial in Goiás data of milling quality were obtained also. Data of the amilose content and gelatinization temperature were collected according to classification criteria of the Centro Internacional de Agricultura Tropical (CIAT 1989) and cooking tests realized. The grains were also classified in long-fine (Lf), long $(\mathrm{L})$, medium $(\mathrm{M})$, and short $(\mathrm{C})$.

In the trials of Goiás and Roraima the lines were evaluated for yield with ratoon cultivation. The plants on the plots were therefore cut after the main crop harvest at a height of about $15 \mathrm{~cm}$ and a topdressing of $50 \mathrm{~kg}$ of nitrogen $\mathrm{ha}^{-1}$ was applied. The following data were collected: number of tillers panicles ${ }^{-1}$ in the same sampling area of the main crop, grain yield in $\mathrm{kg} \mathrm{ha}^{-1}$, and yield of intact and total grains in the trial conducted in Goiás.

The data of grain yield of the main crop and ratooning underwent the individual and joint analysis of variance and the means were compared by the test of Scott and Knott (1974) at 5\% probability. 


\section{RESULTSAND DISCUSSION}

\section{Heterosis tests}

Table 1 shows the number of panicles (Pan) and the grain yield in $\mathrm{kg} \mathrm{ha}^{-1}$ of the $\mathrm{RC}_{2} \mathrm{~F}_{2}$ families of the trial conducted in the crop year 1999/00 in Goiás and the number of panicles (Pan) and grain yield in $\mathrm{kg} \mathrm{ha}^{-1}$ of the same families in the $\mathrm{RC}_{2} \mathrm{~F}_{4}$ generation of the trial conducted in the crop year 2000/01 in Goiás, Tocantins and Roraima. Significant differences were observed at a probability level of $5 \%$ between the means of the families for the traits number of panicles and grain yield in the two generations $\mathrm{RC}_{2} \mathrm{~F}_{2}$ and $\mathrm{RC}_{2} \mathrm{~F}_{4}$. The coefficient of variation for grain yield in the $\mathrm{RC}_{2} \mathrm{~F}_{2}$ generation $(21 \%)$ was somewhat superior to that obtained for the same trait in the $\mathrm{RC}_{2} \mathrm{~F}_{4}$ generation (Table 1). This can be explained by the fact that one is dealing with a segregant population from a interspecific crossing, where there is a larger variability among and within families in the $\mathrm{RC}_{2} \mathrm{~F}_{2}$ than in the $\mathrm{RC}_{2} \mathrm{~F}_{4}$ generation.

Of the 18 families selected in the $\mathrm{RC}_{2} \mathrm{~F}_{2}$ generation ten (CNAi 9920, CNAi 9921, CNAi 9922, CNAi 9923, CNAi 9924, CNAi 9925, CNAi 9926, CNAi 9927, CNAi 9928 and CNAi 9929) presented an estimated percentage of the Oryza glumaepatula genome varying from 26\% (CNAi 9921) to 7.6\% (CNAi 9924). All of these produced a larger number of panicles than the genitor BG 90-2. CNAi 9920 presented an increase of $145.8 \%$ in the number of panicles per plant in relation to BG $90-2$ and possesses $12.6 \%$ of the wild species' genome. Eight families (CNAi 9930, CNAi 9931, CNAi 9932, CNAi 9933, CNAi 9934, CNAi 9935, CNAi 9936 and CNAi 9937) did not have detectable chromosome segments of the wild species at the saturation level of the linkage map in use (1 marker for every $10 \mathrm{cM})$. They were however transgressive for grain yield in relation to control

Table 1. Percentage of Oryza glumaepatula in the genome (\% O glum.), number of panicles per cova/planting spot (PAN), mean yield in $\mathrm{kg} \mathrm{ha}^{-1}$ in Goiás, (GO), Roraima (RR) and Tocantins (TO) and mean of the three sites of the $\mathrm{RC}_{2} \mathrm{~F}_{2}$ and $\mathrm{RC}_{2} \mathrm{~F}_{4}$ families evaluated in the crop years 1999/00 and 2000/01, respectively

\begin{tabular}{|c|c|c|c|c|c|c|c|c|}
\hline \multirow[t]{3}{*}{ Families } & \multirow{3}{*}{$\begin{array}{c}\text { O. glum. } \\
\%\end{array}$} & \multicolumn{2}{|r|}{$\mathbf{R C}_{2} \mathbf{F}_{2}$} & \multirow{3}{*}{ PAN } & \multicolumn{4}{|c|}{$\mathbf{R C}_{2} \mathbf{F}_{4}$} \\
\hline & & PAN & Yield $\mathrm{kg} \mathrm{ha}^{-1}$ & & \multicolumn{4}{|c|}{ Yield $\mathrm{kg} \mathrm{ha}{ }^{-1}$} \\
\hline & & & G O & & Mean & G O & $\mathbf{R} \mathbf{R}$ & TO \\
\hline CNAi 9934 & & $8 \mathrm{c}$ & 9757 a & $13 \mathrm{~b}$ & 9464 a & 9672 a & 12148 a & $6573 \mathrm{a}$ \\
\hline CNAi 9937 & & $7 \mathrm{c}$ & 9084 a & $12 \mathrm{~b}$ & 9321 a & $10256 \mathrm{a}$ & $11175 \mathrm{a}$ & $6531 \mathrm{a}$ \\
\hline CNAi 9936 & & $8 \mathrm{c}$ & $9660 \mathrm{a}$ & $15 \mathrm{a}$ & $9255 \mathrm{a}$ & $10177 \mathrm{a}$ & 10953 a & $6635 \mathrm{a}$ \\
\hline BG 90-2 & & $7 \mathrm{c}$ & 8118 a & $13 \mathrm{~b}$ & $9201 \mathrm{a}$ & 9828 a & $10995 \mathrm{a}$ & $6781 \mathrm{a}$ \\
\hline CNAi 9931 & & $10 \mathrm{~b}$ & 9967 a & $15 \mathrm{a}$ & 9178 a & 9531 a & 11439 a & 6563 a \\
\hline CNAi 9930 & & $9 \mathrm{c}$ & 10413 a & $13 \mathrm{~b}$ & 9135 a & 9839 a & $11161 \mathrm{a}$ & 6406 a \\
\hline CNAi 9935 & & $8 \mathrm{c}$ & $9754 \mathrm{a}$ & $12 \mathrm{~b}$ & $9110 \mathrm{a}$ & 9643 a & 10894 a & 6792 a \\
\hline CNAi 9932 & & $9 \mathrm{c}$ & 9940 a & $16 \mathrm{a}$ & 8929 a & 9244 a & 10847 a & 6698 a \\
\hline CNAi 9933 & & $9 \mathrm{c}$ & 9823 a & $12 \mathrm{~b}$ & $8362 \mathrm{~b}$ & 8440 b & 10314 a & $6333 \mathrm{a}$ \\
\hline BRS Formoso & & & & $13 \mathrm{~b}$ & 8324 b & $8350 \mathrm{~b}$ & $10560 \mathrm{a}$ & $6063 \mathrm{~b}$ \\
\hline CNAi 9924 & 7.6 & $11 \mathrm{~b}$ & 8908 a & $12 \mathrm{~b}$ & 8066 b & $7897 \mathrm{de}$ & 10466 a & $5833 \mathrm{~b}$ \\
\hline CNAi 9927 & 9.8 & $10 \mathrm{~b}$ & $6067 \mathrm{~b}$ & 15 a & $7399 \mathrm{c}$ & $8050 \mathrm{~b}$ & $8521 \mathrm{~b}$ & $5625 \mathrm{~b}$ \\
\hline CNAi 9925 & 9.0 & $11 \mathrm{~b}$ & 7742 a & $12 \mathrm{~b}$ & $6907 \mathrm{~d}$ & $7923 \mathrm{c}$ & $7881 \mathrm{~b}$ & $4917 \mathrm{c}$ \\
\hline CNAi 9923 & 9.8 & $11 \mathrm{~b}$ & $6134 \mathrm{~b}$ & $13 \mathrm{~b}$ & $6730 \mathrm{~d}$ & $7370 \mathrm{c}$ & $7183 \mathrm{c}$ & $5635 \mathrm{~b}$ \\
\hline CNAi 9926 & 11.9 & $11 \mathrm{~b}$ & $6873 \mathrm{~b}$ & $12 \mathrm{~b}$ & $6614 \mathrm{~d}$ & $6925 \mathrm{c}$ & $8354 \mathrm{~b}$ & $4563 \mathrm{c}$ \\
\hline CNAi 9928 & 11.3 & $10 \mathrm{~b}$ & $5834 \mathrm{~b}$ & $14 \mathrm{a}$ & $6565 \mathrm{~d}$ & $6236 \mathrm{~d}$ & 8896 b & $4563 \mathrm{c}$ \\
\hline CNAi 9929 & 12.5 & $10 \mathrm{~b}$ & 7496 a & $13 \mathrm{~b}$ & $6549 \mathrm{~d}$ & $7798 \mathrm{c}$ & $7204 \mathrm{c}$ & $4646 \mathrm{c}$ \\
\hline CNAi 9920 & 12.6 & $18 \mathrm{a}$ & 8288 a & 15 a & $5986 \mathrm{e}$ & $5849 \mathrm{~d}$ & $7058 \mathrm{c}$ & $5052 \mathrm{c}$ \\
\hline CNAi 9921 & 26.0 & $12 \mathrm{~b}$ & $3167 \mathrm{c}$ & $14 \mathrm{a}$ & $5944 \mathrm{e}$ & $6181 \mathrm{~d}$ & $6985 \mathrm{c}$ & $4667 \mathrm{c}$ \\
\hline CNAi 9922 & 15.8 & $11 \mathrm{~b}$ & $2131 \mathrm{c}$ & $14 \mathrm{a}$ & $5256 \mathrm{f}$ & $5409 \mathrm{~d}$ & $5744 \mathrm{~d}$ & $4615 \mathrm{c}$ \\
\hline BR-IRGA 409 & & $7 \mathrm{c}$ & $5431 \mathrm{~b}$ & & & & & \\
\hline Mean & & 8 & 7326 & 13 & 7814 & 8230 & 9438 & 5774 \\
\hline $\mathrm{CV} \%$ & & 14 & 21 & 17 & 9 & 11 & 7 & 7 \\
\hline
\end{tabular}

Test of means by Scott and Knott (1974) at 5\% probability 
BG 90-2. CNAi 9930 stood out among the others for producing in the mean $10413 \mathrm{~kg} \mathrm{ha}^{-1}$ of grain (Table 1).

The eight transgressive families attained a similar yield in $\mathrm{RC}_{2} \mathrm{~F}_{4}$ to that of the $\mathrm{RC}_{2} \mathrm{~F}_{2}$ generation and the 10 families selected for the number of panicles presented the same performance in both generations (Table 1). This is an evidence that the positive alleles of Oryza glumaepatula were responsible for the effects of increase in the number of panicles and yield. Among the ten families with the highest panicle number, CNAi 9924, which also presented high grain yields in the two generations of evaluation, and CNAi 9920, which produced $8288 \mathrm{~kg} \mathrm{ha}^{-1}$ in the $\mathrm{RC}_{2} \mathrm{~F}_{2}$ generation were subjected to molecular marker-assisted selection. Based on the QTL mapping analysis in $\mathrm{RC}_{2} \mathrm{~F}_{2}$, plants of these two families that contained the favorable allele for traits related to grain production or alleles in homozygosis for BG 90-2 in regions that contained large fragments of the O. glumaepatula genome were selected by assisted selection.

\section{Molecular microsatellite marker-assisted selection (SSR) in two $\mathrm{RC}_{2} \mathrm{~F}_{6}$ families}

Favorable alleles for the genitor BG 90-2 and RS-16 were identified (Table 2) in $\mathrm{RC}_{2} \mathrm{~F}_{6}$ plants of the CNAi 9920 and CNAi 9924 families. Of the 104 genotyped plants in the family CNAi 9920 , ten presented all favorable alleles in homozygosis for BG 90-2 (plants 27, 55, 60, 62, 74, 78, 82, 88,89 , and 92 ), and three plants with favorable alleles in homozygosis for RS-16 (plants 1, 25 and 40) (Table 3).

Of the 168 genotyped plants of family CNAi 9924 , 118 bearers of both favorable alleles from the genitor BG 90-2 were identified (Table 3). Seventeen plants amongst these were selected for a new evaluation and phenotypic selection in the following generation, totalizing, for both families, $30 \mathrm{RC}_{2} \mathrm{~F}_{6}$ plants. Three plants selected from family CNAi 9924 (plants 77, 125 and 153) were observed in the $\mathrm{RC}_{2} \mathrm{~F}_{7}$ generation which had very long awn; these were discarded since this trait was inherited from the wild parent O. glumaepatula. The evaluation proceeded with these 27 lines plus the eight 8 initially selected lines, amounting to a total of 35 lines.

\section{Phenotypic evaluation of 35 Oryza sativa lines with gene introgression of the wild species Oryza glumaepatula}

The individual and joint analyses of variance for the trait grain yield in the main crop were significantly different at a 5\% probability level by the test of Scott and Knott (1974) (Table 4). The coefficients of variation (CVs) of the trials varied from $9 \%$ (trial of Goiás) to $23 \%$ (trial of Tocantins), considered a good result for experiments conducted in the field and for a quantitative trait such as grain yield.
The mean yield of the three trials was $5885 \mathrm{~kg} \mathrm{ha}^{-1}$; the greatest was obtained in the trial of Goiás $\left(8010 \mathrm{~kg} \mathrm{ha}^{-1}\right)$ and the smallest in Tocantins (4122 $\left.\mathrm{kg} \mathrm{ha}^{-1}\right)$. The lines CNAi 9937, CNAi 9931 and CNAi 9934 were the most productive in the main crop ( 7398,7338 and $7135 \mathrm{~kg} \mathrm{ha}^{-1}$, respectively) but did not differ significantly from the controls BG 90-2 and Metica 1 (Table 4). Considering only the trials of Goiás and Roraima (Table 5), the mean yield of the two sites in the main crop was $6767 \mathrm{~kg} \mathrm{ha}^{-1}$ with the lines CNAi 9937, CNAi 9931 and CNAi 9934 producing around $8000 \mathrm{~kg} \mathrm{ha}^{-1}$, and differing significantly from Metica 1, considered the most productive commercial cultivar in the tropical region of Brazil.

The flowering mean of the lines varied from 88 to 95 days, in line with the flowering range of the controls. All lines presented modern plant architecture with a height of about $100 \mathrm{~cm}$, high lodging resistance and upright leaves that stayed green until grain maturation, a trait which is of great importance for being related to high yield in irrigated rice (Table 4).

In the trial conducted in Tocantins, the lines presented high scores for the main rice diseases blast, brown spot, grain spot and leaf scald (Table 4) causing an expressive reduction in the grain yield, evidencing how stressful an environment are the lowland of Tocantins.

The use of the ratoon is a common practice in some countries, as for example the United States (Bollich and Turner 1988), and may be a low-cost alternative to increase the profitability of irrigated rice plantations in Brazil (Santos 1999). Besides the high plant vigor, O. sativa lines with gene introgression from the wild species $O$. glumaepatula presented a strong capacity of regrowth, making the use of the ratoons feasible. This trait was evaluated in the trials conducted in Goiás and Roraima, whose data of grain yield of the main crop, of the ratoon, of the sum of both and the number of tillers and panicles are shown in Table 5.

Except for the ratoon in the experiment of Roraima, significant differences were observed by the test of Scott and Knott (1974) at a probability of 5\% for the trait grain yield for the main crop, ratoon and the sum of both in the mean of the environments where the trials had been conducted. The lines CNAi 9937, CNAi 9935, CNAi 9931, CNAi 9936, CNAi 9934, and CNAi 9930 produced in the sum of the main and the ratoon crop over $10.000 \mathrm{~kg} \mathrm{ha}^{-1}$ (Table 5) and were significantly superior to control Metica 1 . Regarding the mean grain yield of both sites and of the main and the ratoon crop separately, these same lines presented statistical superiority to the control Metica 1. Mean grain yields in the ratoon crop of the lines CNAi 9935 and CNAi 9936 were $2627 \mathrm{~kg} / \mathrm{ha}$ and $2688 \mathrm{~kg} \mathrm{ha}^{-1}$ respectively, which made up 34 and $35 \%$ of the yield obtained in the main crop.

In general, the evaluated families presented a high number of tillers and panicles $\mathrm{m}^{-2}$ in relation to the controls 
Table 2. Alleles selected by the microsatellite markers used in the individual analysis in the $\mathrm{RC}_{2} \mathrm{~F}_{6}$ generation of the crossing Oryza sativa (BG 90-2) x Oryza glumaepatula (RS-16)

\begin{tabular}{|c|c|c|c|c|}
\hline Line & Marker & Chromosome & Allele to be selected & $\%$ Explained phenotypic variation ${ }^{1}$ \\
\hline \multirow[t]{11}{*}{ CNAi 9920} & OG60 & 4 & BG $90-2$ & $17.06(\mathrm{PLH})$ \\
\hline & & & & 23.86 (PFG) \\
\hline & & & & $20.28(\mathrm{FGP})$ \\
\hline & & & & $31.72(\mathrm{GYPa})$ \\
\hline & OG99 & 3 & BG 90-2 & - \\
\hline & OS22 & 7 & BG 90-2 & - \\
\hline & RM1 & 1 & BG $90-2$ & 48.37 (SPP) \\
\hline & & & & 39.11 (GYP) \\
\hline & & & & $42.39(\mathrm{FGP})$ \\
\hline & & & & $31.17(\mathrm{GYPa})$ \\
\hline & RM 2 & 7 & BG 90-2 & - \\
\hline \multirow[t]{17}{*}{ CNAi 9924} & $\mathrm{RM} 4 \mathrm{~b}$ & 11 & BG $90-2$ & 13.54 (PFG) \\
\hline & & & & $13.25(\mathrm{HGW})$ \\
\hline & & & & $20.82(\mathrm{GYPa})$ \\
\hline & RM 10 & 7 & BG 90-2 & $12.95(\mathrm{HGW})$ \\
\hline & RM 11 & 7 & BG 90-2 & $15.60(\mathrm{PLH})$ \\
\hline & & & & $17.94(\mathrm{HGW})$ \\
\hline & & & & $13.88(\mathrm{GYP})$ \\
\hline & RM 44 & 8 & RS-16 & 32.57 (TNR) \\
\hline & & & & 30.82 (PNR) \\
\hline & RM 163 & 5 & BG 90-2 & - \\
\hline & RM 223 & 8 & RS-16 & 32.57 (TNR) \\
\hline & & & & 30.82 (PNR) \\
\hline & OG60 & 4 & BG 90-2 & $17.06(\mathrm{PLH})$ \\
\hline & & & & 23.86 (PFG) \\
\hline & & & & $20.28(\mathrm{FGP})$ \\
\hline & & & & $31.72(\mathrm{GYPa})$ \\
\hline & RM 261 & 4 & BG 90-2 & $12.71(\mathrm{HGW})$ \\
\hline
\end{tabular}

${ }^{1}$ PLH: panicle length; PFG: percentage of filled grains; FGP: filled grains per panicle; GYPa: yield per panicle; SPP: spikelets per panicle; GYP: yield per plant; HGW: weight of 100 seeds; TNR: number of tillers; PNR: number of panicles

Table 3. Number of homozygote plants that obtained amplification with the markers tested in the lines CNAi 9920 and CNAi 9924

\section{CNAi 9920: 11 tested markers}

$\mathrm{Nr}$ of favorable amplified alleles

$\mathrm{Nr}$ of identified plants

$\begin{array}{lllllll}9 & 8 & 7 & 5 & 4 & 3 & 2\end{array}$

$\begin{array}{lllllll}10 & 14 & 22 & 7 & 13 & 3 & 2\end{array}$

CNAi 9924: 2 tested markers

$\mathrm{Nr}$ of favorable amplified alleles

$\mathrm{Nr}$ of identified plants

$\begin{array}{ccc}2 & 1 & 0 \\ 118 & 46 & 4\end{array}$

BG 90-2 and Metica 1, although there were no significant differences (Table 5). Of the most productive families in the sum of the main and the ratoon crop, CNAi 9935 presented 515 tillers and 511 panicles $\mathrm{m}^{-2}$. This trait is highly important for irrigated rice, since it contributes to compensate missing plants in the stand of plantations, requiring a smaller quantity of seeds per hectare and reducing the costs of the plantation.

In general, the lines presented high milling quality and high amilose content and gelatinization temperature. In the cooking tests, most lines presented grains that were slightly sticky after cooking, a trait considered undesirable by Brazilian consumers. Line CNAi 9930 however stood out from the others for presenting a high milling quality in the main $(65 \%)$ and in the ratoon crop (50\%), and loose grains after cooking. This line was also one of the most productive in the sum of the mean yield of the main and the ratoon crop (Table 5). Other lines such as CNAi 9920-1, CNAi 9920-55, CNAi 9920-62, CNAi 9920-78, and CNAi 9924-55 (line with long-fine grain) presented high milling quality in the main and ratoon crop besides presenting loose grains after cooking. This 
PHN Rangel et al.

Table 4. Evaluated data of mean grain yield (GY) in Goiás (GO), Tocantins (TO) and Roraima (RR) and mean yield of the three sites, mean flowering (FLO), plant height (PH), lodging (LODG), panicle blast (PB), brown spot (BS), grain spot (GS), leaf scald (LSC) and phenotypic acceptance (PA) of the Oryza sativa lines with gene introgression of the wild species Oryza glumaepatula

\begin{tabular}{|c|c|c|c|c|c|c|c|c|c|c|c|c|c|}
\hline Treat. & Line & GY & GO & TO & $\mathbf{R R}$ & FLO & $\mathbf{P H}$ & LODG & PB & B S & GS & LSC & PA \\
\hline 8 & CNAi 9937 & 7398 a & 9063 a & $6051 \mathrm{a}$ & $7080 \mathrm{a}$ & 90 & 99 & 1 & 5 & 5 & 3 & 7 & 5 \\
\hline 2 & CNAi 9931 & 7338 a & 9292 a & 5919 a & $6804 \mathrm{a}$ & 89 & 100 & 1 & 5 & 7 & 5 & 9 & 5 \\
\hline 5 & CNAi 9934 & $7135 \mathrm{a}$ & $9135 \mathrm{a}$ & 5439 a & $6830 \mathrm{a}$ & 90 & 97 & 1 & 7 & 7 & 5 & 9 & 5 \\
\hline 1 & CNAi 9930 & 6998 a & 9083 a & 4752 a & 7159 a & 89 & 99 & 1 & 7 & 5 & 5 & 7 & 5 \\
\hline 7 & CNAi 9936 & $6836 \mathrm{a}$ & 8365 a & 5313 a & $6830 \mathrm{a}$ & 89 & 99 & 1 & 7 & 7 & 5 & 7 & 5 \\
\hline 36 & BG 90-2 & $6755 \mathrm{a}$ & 8781 a & 4878 a & $6607 \mathrm{a}$ & 90 & 97 & 1 & 9 & 7 & 7 & 9 & 5 \\
\hline 37 & METICA 1 & 6696 a & 8802 a & 5440 a & $5845 \mathrm{a}$ & 95 & 106 & 1 & 5 & 5 & 5 & 7 & 3 \\
\hline 32 & CNAi $9924-117$ & $6610 \mathrm{~b}$ & 8458 a & $5197 \mathrm{a}$ & $6174 \mathrm{a}$ & 88 & 94 & 1 & 9 & 7 & 5 & 9 & 5 \\
\hline 6 & CNAi 9935 & $6571 \mathrm{~b}$ & $9031 \mathrm{a}$ & $4115 \mathrm{~b}$ & $6568 \mathrm{a}$ & 89 & 99 & 1 & 9 & 7 & 3 & 7 & 5 \\
\hline 21 & CNAi 9920-92 & $6514 \mathrm{~b}$ & 8469 a & 4702 a & $6371 \mathrm{a}$ & 89 & 100 & 1 & 7 & 5 & 5 & 7 & 5 \\
\hline 4 & CNAi 9933 & $6422 \mathrm{~b}$ & 8271 a & 4546 a & 6449 a & 89 & 101 & 1 & 7 & 7 & 5 & 9 & 5 \\
\hline 31 & CNAi 9924-105 & $6301 \mathrm{~b}$ & 8885 a & 5053 a & $4965 \mathrm{~b}$ & 88 & 97 & 1 & 5 & 7 & 5 & 7 & 3 \\
\hline 29 & CNAi 9924-85 & $6141 \mathrm{~b}$ & 8010 a & 4239 a & $6174 a$ & 87 & 99 & 1 & 7 & 7 & 5 & 9 & 5 \\
\hline 35 & CNAi 9924-164 & $6102 \mathrm{~b}$ & $8115 \mathrm{a}$ & $3596 \mathrm{~b}$ & $6594 \mathrm{a}$ & 88 & 98 & 1 & 7 & 7 & 7 & 7 & 7 \\
\hline 3 & CNAi 9932 & $6065 \mathrm{~b}$ & $7667 \mathrm{~b}$ & $4327 \mathrm{a}$ & $6200 \mathrm{a}$ & 89 & 96 & 1 & 7 & 7 & 5 & 7 & 5 \\
\hline 30 & CNAi $9924-92$ & $5999 \mathrm{~b}$ & 8146 a & $4096 \mathrm{~b}$ & 5753 a & 88 & 98 & 1 & 7 & 7 & 5 & 9 & 3 \\
\hline 38 & CNA 8502 & $5975 \mathrm{~b}$ & 7958 a & 4357 a & 5609 a & 85 & 98 & 1 & 3 & 3 & 3 & 7 & 5 \\
\hline 28 & CNAi 9924-61 & $5928 \mathrm{c}$ & $7927 \mathrm{a}$ & $4076 \mathrm{~b}$ & $5780 \mathrm{a}$ & 87 & 95 & 1 & 9 & 9 & 7 & 9 & 5 \\
\hline 18 & CNAi $9920-82$ & $5806 \mathrm{c}$ & $7375 \mathrm{~b}$ & $4526 \mathrm{a}$ & 5518 a & 90 & 93 & 1 & 9 & 7 & 5 & 9 & 5 \\
\hline 26 & CNAi 9924-41 & $5774 \mathrm{c}$ & 8948 a & $2817 \mathrm{~b}$ & $5556 \mathrm{a}$ & 87 & 93 & 1 & 9 & 7 & 5 & 9 & 3 \\
\hline 25 & CNAi 9924-37 & $5771 \mathrm{c}$ & 8667 a & $3669 \mathrm{~b}$ & $4978 \mathrm{~b}$ & 88 & 98 & 1 & 9 & 7 & 7 & 9 & 5 \\
\hline 24 & CNAi 9924-23 & $5688 \mathrm{c}$ & 8271 a & $3447 \mathrm{~b}$ & $5346 \mathrm{~b}$ & 86 & 95 & 1 & 9 & 7 & 7 & 9 & 3 \\
\hline 23 & CNAi $9924-15$ & $5598 \mathrm{c}$ & 8000 a & $3014 \mathrm{~b}$ & 5780 a & 90 & 97 & 1 & 9 & 9 & 5 & 9 & 5 \\
\hline 9 & CNAi 9920-1 & $5491 \mathrm{c}$ & $6604 \mathrm{~b}$ & $4010 \mathrm{~b}$ & 5858 a & 87 & 95 & 1 & 7 & 7 & 5 & 9 & 7 \\
\hline 34 & CNAi 9924-142 & $5430 \mathrm{c}$ & $8510 \mathrm{a}$ & $4000 \mathrm{~b}$ & $3780 \mathrm{~b}$ & 91 & 97 & 1 & 9 & 7 & 7 & 9 & 3 \\
\hline 14 & CNAi $9920-60$ & $5387 \mathrm{c}$ & $7688 \mathrm{~b}$ & $3970 \mathrm{~b}$ & $4503 \mathrm{~b}$ & 89 & 97 & 1 & 7 & 7 & 5 & 7 & 5 \\
\hline 22 & CNAi 9924-3 & $5374 \mathrm{c}$ & $7531 \mathrm{~b}$ & 4422 a & $4170 \mathrm{~b}$ & 88 & 94 & 1 & 9 & 7 & 5 & 9 & 5 \\
\hline 19 & CNAi $9920-88$ & $5345 \mathrm{c}$ & $7750 \mathrm{~b}$ & $3124 \mathrm{~b}$ & $5162 \mathrm{~b}$ & 93 & 99 & 1 & 9 & 7 & 7 & 9 & 5 \\
\hline 27 & CNAi $9924-55$ & $5344 \mathrm{c}$ & 8542 a & $3545 \mathrm{~b}$ & $3945 \mathrm{~b}$ & 86 & 91 & 1 & 9 & 7 & 5 & 9 & 5 \\
\hline 20 & CNAi 9920-89 & $5246 \mathrm{c}$ & $7000 \mathrm{~b}$ & 4271 a & $4467 \mathrm{~b}$ & 90 & 96 & 1 & 5 & 7 & 5 & 9 & 5 \\
\hline 33 & CNAi $9924-138$ & $5219 \mathrm{c}$ & 8500 a & $3126 \mathrm{~b}$ & $4032 \mathrm{~b}$ & 88 & 95 & 1 & 9 & 7 & 7 & 9 & 3 \\
\hline 13 & CNAi $9920-55$ & $5044 \mathrm{c}$ & $6781 \mathrm{~b}$ & $3908 \mathrm{~b}$ & $4442 \mathrm{~b}$ & 89 & 94 & 1 & 7 & 7 & 7 & 7 & 5 \\
\hline 10 & CNAi 9920-25 & $5040 \mathrm{c}$ & $6667 \mathrm{~b}$ & $3880 \mathrm{~b}$ & $4574 \mathrm{~b}$ & 88 & 88 & 1 & 9 & 9 & 5 & 9 & 7 \\
\hline 12 & CNAi $9920-40$ & $5022 \mathrm{c}$ & $6010 \mathrm{~b}$ & $3895 \mathrm{~b}$ & $5162 \mathrm{~b}$ & 88 & 96 & 1 & 7 & 7 & 5 & 9 & 7 \\
\hline 11 & CNAi $9920-27$ & $4960 \mathrm{c}$ & $6688 \mathrm{~b}$ & $2754 \mathrm{~b}$ & 5438 a & 93 & 99 & 1 & 9 & 7 & 7 & 9 & 5 \\
\hline 15 & CNAi 9920-62 & $4940 \mathrm{c}$ & $7438 \mathrm{~b}$ & $2863 \mathrm{~b}$ & $4519 \mathrm{~b}$ & 90 & 97 & 1 & 9 & 7 & 5 & 9 & 5 \\
\hline 17 & CNAi 9920-78 & $4708 \mathrm{c}$ & $7083 \mathrm{~b}$ & $2500 \mathrm{~b}$ & $4542 \mathrm{~b}$ & 89 & 96 & 1 & 9 & 7 & 5 & 9 & 5 \\
\hline \multirow[t]{3}{*}{16} & CNAi $9920-74$ & $4677 \mathrm{c}$ & $6865 \mathrm{~b}$ & $2818 \mathrm{~b}$ & $4348 \mathrm{~b}$ & 93 & 95 & 1 & 9 & 7 & 5 & 9 & 5 \\
\hline & Mean & 5885 & 8010 & 4122 & 5524 & & & & & & & & \\
\hline & $\mathrm{CV} \%$ & 15 & 9.5 & 23 & 16 & & & & & & & & \\
\hline
\end{tabular}

Test of means by Scott and Knott (1974) at $5 \%$ probability 
Table 5. Data of mean grain yield in $\mathrm{kg} \mathrm{ha}^{-1}$ of the main (MC) and the ratoon crop (RAT) together and separately and number of tillers (Ti) and panicles (Pan) of the O. sativa lines with gene introgression from the wild species O. glumaepatula evaluated in trials conducted in Goiás and Roraima

\begin{tabular}{|c|c|c|c|c|c|c|c|c|c|c|c|c|}
\hline \multirow[t]{2}{*}{ Treat. } & \multirow[t]{2}{*}{ Line } & \multicolumn{3}{|c|}{ Mean of the two sites } & \multicolumn{3}{|c|}{ Goiás } & \multicolumn{3}{|c|}{ Roraima } & \multirow[t]{2}{*}{$\mathbf{T i}$} & \multirow[t]{2}{*}{ Pan } \\
\hline & & SUM & MC & RAT & SUM & MC & RAT & SUM & MC & RAT & & \\
\hline 8 & CNAi 9937 & 10469 a & 8071 a & 2398 a & $12197 \mathrm{a}$ & $9063 \mathrm{a}$ & 3135 a & 8740 a & 7080 a & $1660 \mathrm{a}$ & & 399 \\
\hline 6 & CNAi 9935 & 10426 a & 7799 a & $2627 \mathrm{a}$ & $12875 \mathrm{a}$ & 9031 a & 3844 a & 7978 a & $6568 \mathrm{a}$ & $1411 \mathrm{a}$ & 515 & 511 \\
\hline 2 & CNAi 9931 & $10327 \mathrm{a}$ & 8047 a & $2280 \mathrm{a}$ & $12197 \mathrm{a}$ & 9292 a & 2906 a & 8458 a & 6804 a & $1654 \mathrm{a}$ & 488 & 485 \\
\hline 7 & CNAi 9936 & $10285 \mathrm{a}$ & 7597 a & $2688 \mathrm{a}$ & $12281 \mathrm{a}$ & 8365 a & 3917 a & 8289 a & $6830 \mathrm{a}$ & 1459 a & 63 & 56 \\
\hline 5 & CNAi 9934 & $10282 \mathrm{a}$ & 7982 a & 2299 a & 12052 a & 9135 a & 2917 a & 8512 a & $6830 \mathrm{a}$ & $1681 \mathrm{a}$ & 430 & 420 \\
\hline 1 & CNAi 9930 & $10126 \mathrm{a}$ & 8121 a & $2005 \mathrm{~b}$ & $12010 \mathrm{a}$ & 9083 a & 2927 a & 8242 a & 7159 a & $1084 \mathrm{a}$ & 421 & 419 \\
\hline 36 & BG 90-2 & $9981 \mathrm{a}$ & 7694 a & $2287 \mathrm{a}$ & $11854 \mathrm{a}$ & 8781 a & 3073 a & 8108 a & $6607 \mathrm{a}$ & $1501 \mathrm{a}$ & 408 & 406 \\
\hline 32 & CNAi 9924-117 & 9674 a & $7316 \mathrm{~b}$ & $2358 \mathrm{a}$ & 11437 a & 8458 a & 2979 a & 7911 a & $6174 \mathrm{a}$ & $1737 \mathrm{a}$ & 468 & 462 \\
\hline 35 & CNAi 9924-164 & 9672 a & $7354 \mathrm{~b}$ & 2318 a & $11000 \mathrm{a}$ & 8115 a & 2885 a & 8345 a & 6594 a & 1751 a & 465 & 463 \\
\hline 4 & CNAi 9933 & 9514 a & $7360 \mathrm{~b}$ & $2154 \mathrm{a}$ & $11593 \mathrm{a}$ & 8271 a & 3323 a & 7436 a & 6449 a & 986 a & 472 & 464 \\
\hline 31 & CNAi 9924-105 & 9382 a & $6925 \mathrm{~b}$ & $2457 \mathrm{a}$ & 12229 a & 8885 a & 3344 a & $6535 \mathrm{~b}$ & $4965 \mathrm{~b}$ & $1570 \mathrm{a}$ & & 526 \\
\hline 30 & CNAi 9924-92 & 9363 a & 6949 b & 2413 a & $11500 \mathrm{a}$ & 8146 a & $3354 \mathrm{a}$ & 7226 a & 5753 a & 1473 a & 519 & 515 \\
\hline 29 & CNAi 9924-85 & 9347 a & $7092 \mathrm{~b}$ & $2255 \mathrm{a}$ & $11020 \mathrm{a}$ & 8010 a & $3010 \mathrm{a}$ & 7675 a & $6174 \mathrm{a}$ & 1431 a & 475 & 472 \\
\hline 21 & CNAi 9920-92 & 9323 a & $7419 \mathrm{~b}$ & $1903 \mathrm{~b}$ & 10802 a & 8469 a & $2333 \mathrm{~b}$ & 7844 a & $6371 \mathrm{a}$ & 1473 a & 490 & 486 \\
\hline 3 & CNAi 9932 & 9220 a & $6933 \mathrm{~b}$ & $2286 \mathrm{a}$ & 10968 a & $7667 \mathrm{~b}$ & 3302 a & 7471 a & $6200 \mathrm{a}$ & 1271 a & 400 & 395 \\
\hline 38 & CNA 8502 & $9113 \mathrm{~b}$ & $6783 \mathrm{~b}$ & $2330 \mathrm{a}$ & $11031 \mathrm{a}$ & 7958 a & 3073 a & 7196 a & 5609 a & $1587 \mathrm{a}$ & 448 & 443 \\
\hline 18 & CNAi 9920-82 & $9009 \mathrm{~b}$ & $6446 \mathrm{c}$ & $2563 \mathrm{a}$ & $10729 \mathrm{~b}$ & $7375 \mathrm{~b}$ & 3354 a & $7290 \mathrm{a}$ & 5518 a & 1772 a & & 437 \\
\hline 23 & CNAi 9924-15 & 8902 b & $6890 \mathrm{~b}$ & $2012 b$ & $10635 \mathrm{~b}$ & 8000 a & $2635 \mathrm{~b}$ & 7170 a & $5780 \mathrm{a}$ & $1390 \mathrm{a}$ & 468 & 463 \\
\hline 28 & CNAi 9924-61 & 8881 b & $6853 \mathrm{~b}$ & $2028 \mathrm{~b}$ & $10552 \mathrm{~b}$ & 7927 a & $2625 \mathrm{~b}$ & 7211 a & 5780 a & $1501 \mathrm{a}$ & 449 & 447 \\
\hline 26 & CNAi 9924-41 & $8837 \mathrm{~b}$ & $7252 \mathrm{~b}$ & $1585 \mathrm{~b}$ & 11229 a & 8948 a & $2281 \mathrm{~b}$ & $6446 \mathrm{~b}$ & 5556 a & 889 a & & 466 \\
\hline 37 & METICA 1 & 8807 b & $7323 \mathrm{~b}$ & $1483 \mathrm{~b}$ & $9822 \mathrm{~b}$ & 8802 a & $1021 \mathrm{c}$ & 7791 a & 5845 a & 1946 a & 425 & 419 \\
\hline 25 & CNAi 9924-37 & 8699 b & $6822 b$ & $1877 \mathrm{~b}$ & 11031 a & 8667 a & $2365 \mathrm{~b}$ & $6368 \mathrm{~b}$ & $4978 \mathrm{~b}$ & 1389 a & 518 & 515 \\
\hline 19 & CNAi 9920-88 & $8637 \mathrm{~b}$ & $6456 \mathrm{c}$ & $2181 \mathrm{a}$ & $10500 \mathrm{~b}$ & $7750 \mathrm{~b}$ & $2750 \mathrm{a}$ & $6774 \mathrm{~b}$ & $5162 \mathrm{~b}$ & 1612 a & 399 & 397 \\
\hline 20 & CNAi 9920-89 & $8603 \mathrm{~b}$ & $5733 \mathrm{c}$ & $2870 \mathrm{a}$ & 11072 a & $7000 \mathrm{~b}$ & 4073 a & $6135 \mathrm{~b}$ & $4467 \mathrm{~b}$ & $1668 \mathrm{a}$ & 411 & 398 \\
\hline 33 & CNAi 9924-138 & $8591 \mathrm{~b}$ & $6266 \mathrm{c}$ & $2325 \mathrm{a}$ & $11260 \mathrm{a}$ & 8500 a & $2760 \mathrm{a}$ & $5922 \mathrm{~b}$ & $4032 \mathrm{~b}$ & $1890 \mathrm{a}$ & 514 & 499 \\
\hline 11 & CNAi 9920-27 & $8530 \mathrm{~b}$ & $6062 \mathrm{c}$ & 2467 a & $9843 \mathrm{~b}$ & $6688 \mathrm{~b}$ & 3156 a & 7217 a & 5438 a & 1779 a & 461 & 455 \\
\hline 15 & CNAi 9920-62 & $8456 \mathrm{~b}$ & $5978 \mathrm{c}$ & $2478 \mathrm{a}$ & 10822 a & $7438 \mathrm{~b}$ & 3385 a & $6089 \mathrm{~b}$ & $4519 \mathrm{~b}$ & $1570 \mathrm{a}$ & 451 & 434 \\
\hline 27 & CNAi 9924-55 & $8388 \mathrm{~b}$ & $6243 \mathrm{c}$ & $2144 \mathrm{a}$ & 11427 a & 8542 a & 2885 a & $5349 \mathrm{~b}$ & 3945 b & 1404 a & 469 & 457 \\
\hline 14 & CNAi 9920-60 & $8385 \mathrm{~b}$ & $6095 \mathrm{c}$ & $2290 \mathrm{a}$ & 11072 a & $7688 \mathrm{~b}$ & 3385 a & $5698 \mathrm{~b}$ & $4503 \mathrm{~b}$ & $1195 \mathrm{a}$ & 481 & 470 \\
\hline 34 & CNAi 9924-142 & $8323 \mathrm{~b}$ & $6145 \mathrm{c}$ & $2177 \mathrm{a}$ & $11197 \mathrm{a}$ & 8510 a & $2688 \mathrm{~b}$ & $5448 \mathrm{~b}$ & $3780 \mathrm{~b}$ & $1668 \mathrm{a}$ & 569 & 553 \\
\hline 9 & CNAi 9920-1 & $8280 \mathrm{~b}$ & $6231 \mathrm{c}$ & $2049 \mathrm{~b}$ & $9187 \mathrm{~b}$ & $6604 \mathrm{~b}$ & $2583 \mathrm{~b}$ & 7373 a & 5858 a & $1515 \mathrm{a}$ & 439 & 430 \\
\hline 24 & CNAi 9924-23 & $8279 \mathrm{~b}$ & $6808 \mathrm{~b}$ & $1470 \mathrm{~b}$ & $10239 \mathrm{~b}$ & 8271 a & $1969 \mathrm{~b}$ & $6319 \mathrm{~b}$ & $5346 \mathrm{~b}$ & 973 a & 503 & 493 \\
\hline 13 & CNAi 9920-55 & 8264 b & $5611 \mathrm{c}$ & $2653 \mathrm{a}$ & $10572 \mathrm{~b}$ & $6781 \mathrm{~b}$ & 3792 a & $5956 \mathrm{~b}$ & $4442 \mathrm{~b}$ & $1515 \mathrm{a}$ & 440 & 436 \\
\hline 16 & CNAi 9920-74 & $8132 b$ & $5606 \mathrm{c}$ & $2526 \mathrm{a}$ & $10250 \mathrm{~b}$ & $6865 \mathrm{~b}$ & 3385 a & $6015 \mathrm{~b}$ & $4348 \mathrm{~b}$ & $1667 \mathrm{a}$ & 444 & 464 \\
\hline 17 & CNAi 9920-78 & $8104 \mathrm{~b}$ & $5812 \mathrm{c}$ & 2292 a & $10250 \mathrm{~b}$ & $7083 \mathrm{~b}$ & 3167 a & $5959 \mathrm{~b}$ & $4542 \mathrm{~b}$ & 1417 a & 423 & 410 \\
\hline 22 & CNAi 9924-3 & $7807 \mathrm{~b}$ & $5850 \mathrm{c}$ & $1956 \mathrm{~b}$ & $10416 \mathrm{~b}$ & $7531 \mathrm{~b}$ & 2885 a & $5198 \mathrm{~b}$ & $4170 \mathrm{~b}$ & $1028 \mathrm{a}$ & 455 & 440 \\
\hline 12 & CNAi 9920-40 & $7673 \mathrm{~b}$ & $5586 \mathrm{c}$ & $2087 \mathrm{~b}$ & 8822 b & $6010 \mathrm{~b}$ & 2813 a & $6524 \mathrm{~b}$ & $5162 \mathrm{~b}$ & 1362 a & 443 & 414 \\
\hline \multirow[t]{3}{*}{10} & CNAi 9920-25 & $6987 \mathrm{~b}$ & $5620 \mathrm{c}$ & $1366 \mathrm{~b}$ & $8552 \mathrm{~b}$ & $6667 \mathrm{~b}$ & $1885 \mathrm{~b}$ & $5422 \mathrm{~b}$ & $4574 \mathrm{~b}$ & 847 a & 522 & 506 \\
\hline & Mean & 8976 & 6767 & 2209 & 10962 & 8010 & 2952 & 6991 & 5524 & 1467 & 463 & 455 \\
\hline & $\mathrm{CV} \%$ & 12 & 12 & 25 & 9 & 9 & 20 & 15 & 16 & 33 & 18 & 18 \\
\hline
\end{tabular}

Test of means by Scott and Knott (1974) a 5\% of probability 
group of lines, originated from the marker-assisted selection, was not the most productive (Tables 4 and 5); in other words, considering only this trait, a phenotypic selection of the 8 initial lines would have been more effective. However, lines with larger fragments of $O$. glumaepatula derived from the families CNAi 9920 and CNAi 9924 presented favorable traits for the grain quality that was not found in the parent line BG 90-2. The effect of the incorporation of these fragments on the quality of the rice grain is being evaluated.
9924-92, CNAi9924-85, CNAi9920-92, CNAi9932, CNAi99201, CNAi 9920-55, CNAi 9920-62, CNAi 9920-78, and CNAi 9924-55 can be used immediately as parents in the improvement program of irrigated rice.

2) Line CNAi 9930 stood out from among the others for uniting a larger number of favorable agronomical traits and could be released as commercial cultivar.

3) The AB-QTL methodology was effective in the development of $O$. sativa lines with gene introgression from the wild species $O$. glumaepatula.

\title{
CONCLUSIONS
}

1) The elite lines of $O$. sativa with gene introgression from the wild species $O$. glumaepatula, CNAi 9937, CNAi 9935, CNAi 9931, CNAi 9936, CNAi 9934, CNAi 9930, CNAi 9924-117, CNAi 9924-164, CNAi 9933, CNAi 9924-105, CNAi

\section{ACKNOWLEDGEMENTS}

We thank the Conselho Nacional of Research (CNPq) for financing the studies with wild rice.

\section{Desenvolvimento de linhagens de arroz com introgressão de genes de Oryza gl umaepatula, utilizando a metodologia deAB-QTL}

\begin{abstract}
RESUMO - A espécie silvestre O. glumaepatula, que ocorre no Brasil, vem sendo utilizada pela Embrapa na ampliação da base genética das populações do melhoramento de arroz irrigado. Assim, o objetivo deste trabalho é mostrar e discutir os procedimentos adotados no desenvolvimento de linhagens de O. sativa com introgressão de genes da espécie silvestre $\mathrm{O}$. glumaepatula, e a sua utilização no aumento da produtividade e na ampliação da base genética de populações de arroz irrigado. Inicialmente foi realizada à transferência de genes da espécie silvestre para a cultivada usando a metodologia de AB-QTLs. Posteriormente, baseando-se, nas análises de QTLs e nos dados fenotípicos selecionaram-se 18 famílias para aos testes de heterose. Dentre estas as famílias, CNAi 9020 e CNAi 9024 foram selecionadas e submetidas à seleção assistida por marcadores moleculares microssatélites. Ao final do processo foram obtidas 35 linhagens que possuem como principais características agronômicas o elevado vigor de plântula, grande número de perfilhos e panículas por planta, alta produtividade de grãos no cultivo principal e elevada capacidade de rebrota o que torna o aproveitamento da soca uma alternativa viável.
\end{abstract}

Palavras-chave: arroz irrigado, marcadores microssatélites, linhagens, produtividade de grãos.

\section{REFERENCES}

Bollich CN and Turner FT (1988) Commercial ratoon rice production in Texas, USA. In: IRRI (ed.) Rice ratooning. Publishing International Rice Research Institute, Manila, p. 257-269.
Breseghello F, Rangel PHN and Morais OP (1999) Ganho de produtividade pelo melhoramento genético do arroz irrigado no Nordeste do Brasil. Pesquisa Agropecuária Brasileira 34: 399-407. 
Brondani RPV, Brondani C, Tarchini R and Grattapaglia D (1998) Development, characterization and mapping of microsatellite markers in Eucalyptus grandis and E urophylla. Theoretical and Applied Genetics 97: 816-827.

Brondani C, Brondani RPV, Rangel PHN and Ferreira ME (2001) Development and mapping of Oryza glumaepatula-derived microsatellite markers in the interspecific cross $O$. glumaepatula x O. sativa. Hereditas 134: 59-71.

Brondani C, Rangel PHN, Brondani RPV and Ferreira ME (2002) QTL mapping and introgression of yield-related traits from Oryza glumaepatula to cultivated rice (Oryza sativa) using microsatellite markers. Theoretical and Applied Genetics 104: 1192-1203.

Buso GSC, Rangel PHN and Ferreira ME (1998) Analysis of genetic variability of South-American wild rice populations (Oryza glumaepatula) with isozymes and RAPD markers. Molecular Ecology 7: 107-117.

Buso GSC, Rangel PHN and Ferreira ME (2001) Analysis of random and specific sequences of nuclear and cytoplasmic DNA in diploid and tetraploid American wild rice species (Oryza spp.). Genome 44: 476-494.

Castro E M, Breseguello F, Rangel PHN and Morais OP (1999) Melhoramento do arroz. In: Borém A (ed.). Melhoramento de espécies cultivadas. Editora UFV, Viçosa, p. 95-130.

Cavalheiro ST, Brondani C, Rangel PHN and Ferreira ME (1996) Paternity analysis of $\mathrm{F}_{1}$ interspecific progenies of crosses between $O$. sativa varieties and its wild relative $O$. glumaepatula using SSR and RAPD markers. Brazilian Journal of Genetics 19: 225.

Centro Internacional de Agricultura Tropical (1989) Evaluación de la calidade culinaria y molinera del arroz; guía de estudio para ser usada como complemento de la unidade audiotutorial sobre el mismo tema. CIAT, Cali, 73p. (Serie 04SR-07.01).
Rangel PHN, Guimarães EP and Neves PCF (1996) Base genética das cultivares de arroz (Oryza sativa L.) irrigado do Brasil. Pesquisa Agropecuária Brasileira 31: 349-357.

Rangel PHN, Pereira JÁ, Morais OP, Guimarães EP and Yokokura $\mathrm{T}$ (2000) Ganhos para produtividade de grãos pelo melhoramento genético do arroz (Oryza sativa L.) irrigado no meio norte do Brasil. Pesquisa Agropecuária Brasileira 35: $1595-1604$.

Santos AB (1999) Aproveitamento da soca. In: Vieira NR, Santos $\mathrm{AB}$ and Sant'Ana EP (ed.) A cultura do arroz. Editora Embrapa Arroz e Feijão, Santo Antônio de Goiás, p. 463-492.

Santos PG, Soares PC, Soares AAS, Morais OP and Cornélio VMO (1999) Avaliação do progresso genético obtido em 22 anos no melhoramento do arroz irrigado em Minas Gerais. Pesquisa Agropecuária Brasileira 34: 1889-1896.

Scott AJ and Knott MA (1974) A cluster analysis method for grouping means in the analysis of variance. Biometrics 30: 507-512.

Soares AA, Ramalho MAP and Sousa AF (1994) Estimativas do progresso genético obtido pelo programa de melhoramento de arroz irrigado da EPAMIG na década de oitenta. Pesquisa Agropecuária Brasileira 29: 97-104.

Tanksley SD and Nelson JC (1996) Advanced backcross QTL analysis: a method for the simultaneous discovery and transfer of valuable QTLs from unadapted germplasm into elite breeding lines. Theoretical and Applied Genetics 92: 191203. 